\title{
Яна Тікан
}

Кандидат педагогічних наук, доцент

Національний технічний університет України

«Київський політехнічний інститут імені Ігоря Сікорського»

Київ, Україна

ORCID 0000-0002-4142-1704

Y.Tikan@kpi.ua

\section{Валерія Ющук}

Студентка факультету лінгвістики

Національний технічний університет України

«Київський політехнічний інститут імені Ігоря Сікорського»

Київ, Україна

ValeryValery98@ukr.net

\section{ЛІНГВОСТИЛІСТИЧНІ ОСОБЛИВОСТІ АНГЛОМОВНИХ РЕКЛАМНИХ ТЕКСТІВ ГАЛУЗІ МАШИНОБУДУВАННЯ}

\begin{abstract}
Анотація. Стаття присвячена дослідженню лінгвостилістичних особливостей англомовних рекламних текстів галузі машинобудування. Рекламний текст є однією 3 актуальних тем для лінгвістичних досліджень, оскільки реклама є динамічним явищем, що зумовлює необхідність систематизації лінгвостилістичних особливостей англомовних рекламних текстів. Метою статті $\epsilon$ аналіз використання лінгвостилістичних засобів емоційного впливу в англомовних рекламних текстах галузі машинобудування з урахуванням їх структурної організації. Об'єктом дослідження $\epsilon$ англомовні рекламні тексти галузі машинобудування. У статті теоретично обгрунтовано термінологічний апарат дослідження, а саме, розглянуто різні підходи науковців до тлумачення понять «реклама», «рекламний текст» та «рекламний дискурс». Також розглянуто структурнофункціональні особливості рекламного тексту. У роботі зосереджено увагу на стилістичному забарвленні англомовного рекламного тексту, надано декілька класифікацій провідних науковців, на основі яких було проведено подальший аналіз їх частотності. Матеріалом дослідження слугували офіційні англомовні сайти таких провідних компаній цієї галузі, як BMW, Jaguar, Toyota, Honda, Mazda, Mercedez-Benz, Ford, Lexus, Saturn, Audi, Subaru, Suzuki, Hyundai та інші. Авторами розглянуто приклади використання лінгвостилістичних засобів емоційного впливу в кожному зі структурних елементів англомовного рекламного тексту галузі машинобудування з урахуванням частотності їх вживання. Також проаналізовано особливості їх функціонування в медіатекстах 3 урахуванням прагматики та комунікативних стратегій, спрямованих на реципієнта рекламного повідомлення. В ході аналізу на прикладах розкрито маніпулятивні властивості лінгвостилістичних особливостей англомовних рекламних текстів.
\end{abstract}

Ключові слова: галузь машинобудування; реклама; рекламний текст; рекламний дискурс; лінгвостилістичні особливості; маніпулятивні властивості.

\section{1. ВСТУП}

Реклама сьогодні є невід'ємною частиною суспільного життя, вона визначається частиною культури, що розвивається за своїми власними законами. Ефективність рекламної компанії залежить від мовного оформлення рекламного тексту. Реклама, як результат творчої діяльності, є унікальною. Завдяки цьому, укладання рекламних текстів передбачає абсолютну свободу у виборі засобів вираження закладеної в рекламі ідеї. Саме тому під час розробки рекламного повідомлення використовується найбільш повний спектр різноманітних стилістичних прийомів та лінгвістичних засобів англійської мови.

Специфіку англомовного рекламного тексту, особливості його структури та комунікативні стратегії досліджували провідні лінгвісти в своїх працях: Бернадська, Кафтанджиєв, Коваленко, Кривоносов, Медведєва, Олянич та ін.

Текст реклами є зразком найбільш ефективного використання лінгвістичних засобів. Він, перш за все, характеризується яскраво вираженим прагматичним аспектом, що проявляється в своєрідній організації, яка передбачає ретельний відбір граматичих засобів, 
лексичних одиниць та стилістичних прийомів. В даному дослідженні основна увага зосереджена на лінгвостилістичних особливостях англомовного рекламного тексту галузі машинобудування.

Актуальність статті зумовлена тим, що реклама є динамічним явищем, яке дуже швидко застаріває та змінюється, що, в свою чергу, зумовлює необхідність систематизації лінгвостилістичних особливостей англомовних рекламних текстів в галузі машинобудування та визначення їх прагматичного функціонування.

Метою статті $\epsilon$ аналіз використання лінгвостилістичних засобів емоційного впливу в англомовних рекламних текстах галузі машинобудування 3 урахуванням їх структурнофункціональних властивостей.

\section{2. ТЕОРЕТИЧНЕ ОБГРУНТУВАННЯ}

Американська Маркетингова Асоціація трактує поняття «реклама» наступним чином: «Реклама - це розповсюджена в певній формі інформація не особистісного характеру про товари, послуги чи ідеї, яка призначена для групи осіб (цільової аудиторії) та $є$ оплачуваною певним спонсором» (Edwards, 1981, с. 3). 3 лінгвістичної точки зору реклама є особливою сферою практичної діяльності, продуктом якої є словесні твори - рекламні тексти. Рекламний текст відноситься до найбільш популярних предметів дослідження в сучасній лінгвістиці, що обумовлено його роллю у формуванні думки як окремої людини, так і нації в цілому.

Для того, щоб аналізувати рекламні тексти, необхідно визначитися 3 трактуванням понять "рекламний текст» та "рекламний дискурс», визначити їх природу та основні характеристики. Оскільки на сучасному етапі розвитку мовознавства поняття «рекламний дискурс» є одним з неоднозначних і досі залишається дискусійним серед таких науковців, як Арутюнова, Бацевич, Ван Дейк, Макаров, Селіванова, Девід Нанен та Дебора Шиффрін. У лінгвістиці склалося два основних підходи до розуміння сутності вищезазначеного понятя: структурно-орієнтований (формально-орієнтований) та функціональноорієнтований.

3 точки зору структурно-орієнтованої лінгвістики, дискурс визначається як «мова вище рівня речення або словосполучення» (Schiffrin, Maznevski \& Tannen, 2003, с. 23-25). Таким чином, це поняття ототожнюють 3 поняттям «текст».

Розглядаючи поняття «дискурс» 3 позиції функціонально-орієнтованого підходу, Карасик (2002) визначає дискурс як «зв'язний текст в сукупності з екстралінгвістичними прагматичними, соціокультурними, психологічними та іншими формами; мова, розглянута як цілеспрямована соціальна дія, як компонент, що бере участь у взаємодії людей i механізмах їх свідомості (когнітивних процесах). Подібну точку зору висловлює Красних (1997), яка пише, що «під дискурсом розуміються два або кілька речень, які перебувають між собою в смисловому зв'язку».

Досліджуючи структурну організацію вербального компоненту рекламного тексту найчастіше виокремлюють такі складові: слоган, заголовок, основний текст та фразавідлуння (Медведева, 2003, с. 9).

Основною функцією слогана є привернення уваги споживача до продукту, який рекламується, таким чином змусити клієнта його придбати. Він має на меті вплинути на адресата, спонукаючи його до практичної дії, яка і є необхідною для працівника рекламної сфери. Слоган є відображенням політики компанії виробника та концепції певного товару.

Заголовок - невід'ємна вербальна частина реклами, що містить в собі як основне повідомлення, так і конкретний рекламний аргумент. Він використовується для позначення товару, послуги, виробника тощо. Основним завданням рекламодавців є відображення теми та ідеї повідомлення за допомогою поєднання заголовку і зображення. Через те, що реципієнт не завжди читає основний текст реклами, заголовок визначається найголовнішою складовою рекламного повідомлення. Основним завданням заголовка вважається привернення уваги потенційних покупців для того, щоб зацікавити їх: саме це змусить адресатів прочитати основну частину реклами. 
Основний рекламний текст - це та частина рекламного тексту, яка несе в собі основні відомості про товар, його переваги та застосування, а також підтвердження аргументів, які містяться в заголовку (Медведева, 2003, с. 13).

Фразою-відлунням називають висновок, який узагальнює всі зазначені в основному рекламному тексті аргументи. Вона сама часто виступає в якості останнього аргументу на користь придбання товару. Хоча ця частина і $є$ останньою в структурі тексту реклами, вона все одно відіграє дуже важливу роль, а особливо серед елементів друкованої реклами. Як було зазначено раніше, більшість споживачів не звертають уваги на основний текст, ігноруючи первинну інформацію про продукт, що компенсується як заголовками, так i фразами-відлуннями (Кафтанджиев, 1995, с. 4).

\section{3. МЕТОДИ}

Для проведення дослідження було використано велику низку різноманітних методів: гіпотетико-дедуктивний метод, за допомогою якого відбувся добір фактичного матеріалу; описовий метод для дослідження лінгвостилістичних та прагматичних особливостей рекламного тексту; зіставний метод для розмежування суміжних понять у процесі дослідження; метод кількісного аналізу для зображення частотності стилістичних прийомів в різних структурних компонентах реклами; метод суц̧ільної вибірки для підбору англомовних рекламних текстів в галузі машинобудування; контекстуально-інтерпретаиійний метод для реконструкції авторського (комунікативного) задуму, мотивів і цілей, загального змісту та рецептивної спрямованості рекламного тексту.

\section{4. РЕЗУЛЬТАТИ ТА ОБГОВОРЕННЯ}

\section{1. Лінгвостилістичні особливості англомовних рекламних текстів}

Функції рекламного звернення реалізуються комплексом різнорівневих засобів: лексико-семантичних одиниць, морфологічних елементів, синтаксичних компонентів, мікротекстів. Інформативна функція маркетингових текстів реалізується за рахунок змістовно-фактуальної інформації. Змістовно-фактуальна інформація включає в себе назву фірми, найменування товару та його технічні характеристики. Ця інформація оформлюється за допомогою нейтральної однозначної внеконтекстуальної лексики без використання стилістичної забарвленості, а також за допомогою цифр (Алексеева, 2004, с. 283). Змістовнофактуальна інформація експліцитна за своєю природою, а іiї мовні одиниці зазвичай вживаються в прямих, предметно-логічних, словникових значеннях (Гальперин, 2006, с. 28).

Більш складний комплекс лінгвостилістичних одиниць задіє функція впливу. Щоб визначити, яким чином вона реалізується, звернемося до класифікації Ліча. У своїй класифікації Ліч (Leech, 1966) визначає чотири головні характерні риси успішно функціонуючого рекламного повідомлення:

- залучення уваги;

- утримання уваги;

- запам'ятовуваність;

- сила продажу.

Для досягнення функції впливу та задовільнення вищезазначених факторів успішного рекламного повідомлення, необхідно звернутися до лінгвостилістичного аналізу тексту. При розгляді стилістичного аспекту англомовного рекламного тексту важливо розуміти, які саме принципи та стилістичні особливості мови є визначальним засобом при впливі на аудиторію. Рекламний текст повинен відповідати наступним принципам:

- стислість - головне завдання рекламного повідомлення полягає в передачі основної думки повідомлення, саме тому необхідно позбавлятися надлишкової інформації, яка лише навантажує текст;

- точність - при створенні будь-якого рекламного тексту важливо уважно ставитися до деталей та акцентувати увагу на пропозиції; 
•логічність - смисловий зв'язок в тексті реклами повинен відігравати ключову роль, оскільки стислість викладу не повинна приводити до втрати важливої інформації;

• інформативність - для того, щоб рекламне повідомлення було переконливим для аудиторії, необхідне чітке і послідовне вибудовування аргументів, під час якого слід уникати подвійного тлумачення та неясності в викладенні інформації;

- оригінальність - незвичайний виклад інформації допоможе рекламному повідомленню запам'ятатися та викликати інтерес у споживача;

- виразність - важливою умовою створення ефективності в тексті реклами $\epsilon$ використання яскравих образів та виражальних засобів риторики (Бердышев, 2008, с. 186205).

В силу своєї специфіки рекламний текст має яскраве стилістичне забарвлення. Під час вивчення експресивності рекламних текстів неможливо залишити осторонь засоби виразності, які широко використовуються в текстах даного типу. Саме тому для того, щоб досягти найбільшої ефективності від рекламного повідомлення, його укладачі часто вдаються до різноманітних лінгвостилістичних прийомів та засобів виразності.

В. А. Кухаренко (2000) виділяє такі основні групи стилістичних прийомів:

- лексичні стилістичні прийоми: епітет, метафора, уособлення, метонімія, іронія, гіпербола, гра слів;

- синтаксичні стилістичні прийоми: інверсія, риторичне питання, риторичний оклик, еліпсис, повтори, паралельні конструкції, полісиндетон, асиндетон, апосіопеза;

- лексико-синтаксичні стилістичні прийоми: антитеза, літота, порівняння, перифраз, градація;

- графічні і фонетичні стилістичні прийоми: курсив, заголовні букви, орфографічні помилки, лапки, алітерація, асонанс, рима.

На думку Кулікової (2008), найбільш поширеними для рекламного тексту мовними засобами виразності є: метафора, гіпербола, епітет, уособлення, літота, метонімія, перифраз і алітерація. За допомогою даних засобів рекламодавець легко зможе створити в уяві потенційного покупця вигідний йому образ. Чим суперечливіше виразний засіб, тим він $\epsilon$ ефективнішим (Гончарова, 2008, с. 202-209).

Таким чином, жоден рекламний текст не може обійтися без особливих стилістичних зворотів, так званих стилістичних фігур, які також необхідні для сильнішого впливу на адресата, тим самим надаючи тексту виразності та образності. Оскільки в нашій роботі ми прагнемо детально проаналізувати лінгвостилістичні особливості англомовних рекламних текстів в галузі машинобудування, вважаємо необхідним взяти за основу нашого дослідження класифікацію Кухаренко (2000), аби зосередитися на всіх групах стилістичних прийомів та виокремити ті, що мають найбільшу частотність та вплив на одержувача рекламного повідомлення.

\section{2. Аналіз лінгвостилістичних особливостей структурних складових англомовних рекламних текстів в галузі машинобудування}

Матеріалом нашого дослідження слугували офіційні англомовні сайти таких провідних компаній цієї галузі, як BMW, Jaguar, Toyota, Honda, Mazda, Mercedez-Benz, Ford, Lexus, Saturn, Audi, Subaru, Suzuki, Hyundai та інші. Нами було проаналізовано 200 одиниць дослідження (речення). Аналіз частотності використання стилістичних прийомів в слоганах показав, що найбільш вживаними є повтори (15\%), метафора (11\%), гра слів (8\%), антитеза (8\%) та рима (8\%). Використання повторів дозволяє автору рекламного тексту підкреслити певну особливість рекламованого товару, тим самим звертаючи на неї увагу реципієнта:

New Thinking. New Possibilities (Hyundai, 2015).

Наступним часто вживаним стилістичним прийомом, який належить до лексичної групи, є метафора, оскільки за його допомогою рекламодавець може легко створити в уяві потенційного покупця вигідний для нього образ: 
Find New Roads (Chevrolet, 2017).

Let's go places (Toyota, 2018).

Такий прийом, як рима, частіше за все зустрічається разом з асонансом, оскільки він полягає в повторенні однакових голосних звуків для надання рекламному повідомленню милозвучності та віршованості, а в наведеному прикладі також спостерігаємо вживання паралельної конструкції:

Grace, Space, Pace (Jaguar, 2019).

Гра слів - прийом, який заснований на комічному поєднанні слів. Застосовуючи цей прийом, рекламодавці прагнуть до кращого запам'ятовування тексту, вдаючись до комічного впливу, акцентуючи увагу на певних його компонентах:

Great BritVan (Vauxhall, 2016).

Вищезазначений приклад є слоганом британської компанії Vauxhall, одним із сегментів якої є виготовлення фургонів та вантажівок. За допомогою гри слів увага концентрується на країні виробництва (співзвучність слогану з країною), аби підкреслити якість рекламованого товару. Наступним прикладом вживання гри слів $є$ рекламний слоган компаніï Skoda, де прийом полягає у використанні омонімів:

The Car that Cares (Skoda, 2018).

Широко застосовується й антитеза, оскільки за допомогою антонімічного протиставлення в рекламному тексті можна виокремити товар або його позитивну характеристику:

The best or nothing (Mercedes-Benz, 2019).

Найменш вживаними стилістичними прийомами $є$ паралельні конструкції (4\%), перифраз (4\%), вживання заголовних букв (4\%), уособлення $(3 \%)$ та літота (3\%). Більшої кількості синтаксичних стилістичних прийомів (інверсія, риторичне запитання, еліпсис, полісиндетон, асиндетон та апосіопеза) під час нашого дослідження виявлено не було.

Заголовок - невід'ємна вербальна частина реклами, що містить в собі як основне повідомлення, так і конкретний рекламний аргумент. Під час аналізу лінгвостилістичних особливостей заголовків англомовних рекламних текстів галузі машинобудування ми визначили, що найбільш частотними стилістичними прийомами $\epsilon$ антитеза $(10 \%)$, гіпербола (10\%), уособлення (9\%), повтори (8\%), та перифраз (9\%).

Частіше всього рекламодавці вдаються до використання таких стилістичних фігур, як aнтитеза, що належить до групи лексико-синтаксичних прийомів, та гіпербола - прийом лексичної групи. Спочатку розглянемо використання антонімічного протиставлення:

A beauty on the surface. A beast under the hood (Volvo, 2020).

Shaping Tomorrow's Vehicles Today (Magna, 2019).

Making unique, imaginative designs and making them real (Mazda, 2020).

В першому прикладі компанія Volvo демонструє універсальність свого транспортного засобу, наголошуючи на різних характеристиках, які вдало поєднуються в одному рекламованому продукті. Використання антитези в другому прикладі дозволяє компанії Magna підкреслити сучасність машини, яка відповідає усім вимогам новітнього автоспорту. В останньому прикладі компанія Mazda застосовує антитезу для того, щоб наголосити на можливості рекламованого товару задовольняти всі мрії покупців в реальному часі.

За допомогою поєднання таких стилістичних фігур, як гіпербола та уособлення, рекламованому продукту (в даному випадку транспортному засобу) надаються не тільки перебільшені характеристики (“at the speed of light”), а й ознаки, які не притаманні неживим істотам (“car that thinks"). Одночасне використання двох вищезазначених прийомів створює вдвічі гіперболізоване сприйняття його особливостей:

Imagine a car that thinks at the speed of light (Vauxhall, 2016).

Наступним тропом, за допомогою якого компанії здатні сконцентрувати увагу покупців на рекламованому продукті чи його окремих характеристиках, є повтор:

We make every Car a dream Car (Acura, 2018).

Необхідно відмітити широке використання перифразу - прийому, в якому назва 
рекламованого продукту замінюється описом його основних функцій чи позитивних характеристик. Однак слід зазначити, що рекламодавці іноді зазначають назву рекламованого товару для створення у покупця асоціацій з наведеними за допомогою перифразу рисами:

The icon of toughness is ready for any trail (Toyota, 2018).

Основний текст рекламних повідомлень вирізняється грунтовним описом рекламованої продукції, а саме тому використання декількох стилістичних прийомів одночасно $є$ частим явищем. Під час аналізу лінгвостилістичних особливостей цього структурного компоненту рекламного тексту ми дійшли до висновку, що найбільш частотними стилістичними прийомами є епітет (27\%), інверсія (13\%), метафора (9\%) та повтори (9\%).

Епітет являє собою експресивне, стилістично забарвлене слово чи словосполучення, яке, як правило, засноване на переносі значення. Слід зазначити, що частіше за все такий прийом, як епітет, застосовується разом із іншими виражальними засобами риторики для отримання більшого впливу на реципієнта. Розглянемо приклади використання епітетів разом із синтаксичним стилістичним прийомом - інверсією:

From pencil sketches of beauty and precision, to cars built by masters of their craft, elegant design language is refined to support dynamic performance (Acura, 2018).

Відповідно до результатів дослідження, наступними за частотністю засобами після інверсії є метафора та повтори:

Audi exclusive gives you the opportunity to turn something special into something truly personal (Audi, 2020).

В наведеному прикладі наявне поєднання метафоричного виразу «gives the opportunity», що акцентує увагу реципієнта на отриманні певних можливостей за умови придбання товару, та повторів «something», за допомогою яких автор рекламного тексту описує ймовірні зміни у разі вибору рекламованого продукту.

Фрази-відлуння, в свою чергу, мають подібний до основного тексту набір стилістичних засобів, оскільки вони несуть в собі узагальнюючу раніше зазначену інформацію. Саме тому найбільш частотними стилістичними прийомами є також епітет (21\%), інверсія (14\%), метафора (12\%) та антитеза (9\%). Так, наприклад, компанія Dodge вдало поєднує епіmemu, інверсію та метафору:

With a muscular design and refined styling, the Dodge Durango owns the road (Dodge, 2020).

В вищенаведеному прикладі автор рекламного повідомлення використовує інверсію («With a muscular design and refined styling,...») для того, щоб звернути увагу читача на особливості рекламованого продукту, які зображено за допомогою епітетів «muscular design» та «refined styling». Метафора «owns the road» зображає якість керування автомобілем та більш точно передає сенс повідомлення. Наступним за частотністю використання прийомом $\epsilon$ aнтитеза, в основі якого лежить принцип контрасту:

Rarely seen. Always heard (Maserati, 2020).

В ході нашого дослідження ми визначили, що такі стилістичні прийоми, як метонімія, риторичне запитання, градація та рима були найменш частотними та майже не використовувалися в усіх структурних елементах англомовного рекламного тексту в галузі машинобудування.

\section{5. ВИСНОВКИ І НАПРЯМКИ ПОДАЛЬШИХ ДОСЛІДЖЕНЬ}

Англомовні рекламні тексти посідають важливе місце серед лінгвістичних матеріалів для дослідження. Незважаючи на те, що багато дослідників в своїх працях вже аналізували рекламний текст, його особливості та функції, питання лінгвостилістичної організації англомовних рекламних текстів в галузі машинобудування потребує поглибленого дослідження, адже реклама сьогодення стрімко змінюється разом із технологіями, людьми та світом загалом. Аналіз використання лінгвостилістичних особливостей англомовних рекламних текстів дозволяє простежити лексичний склад даного типу повідомлень, виокремити основні стилістичні прийоми, які застосовують рекламодавці даної галузі, аби 
впливати на реципієнтів.

Аналіз лінгвостилістичних особливостей англомовної реклами в галузі машинобудування показав, що цей жанр текстів містить в собі велику кількість різноманітних стилістичних прийомів, що, в свою чергу, зумовлюють його прагматичне функціонування та маніпулятивний вплив.

Перспективним напрямом подальших наукових досліджень може бути аналіз специфіки перекладу, особливостей відтворення англомовних рекламних текстів галузі машинобудування українською мовою.

\section{СПИСОК ЛІТЕРАТУРИ}

Алексеева, И. С. (2004). Введение в переводоведение. Академия.

Арутюнова, Н. Д. (1999). Язык и мир человека. Языки русской культуры.

Бацевич, Ф. С. (2006). Вступ до лінгвістичної генології. Видавничий центр «Академія».

Бердышев, С. Н. (2008). Рекламный текст. Методика составления и оформления. Дашков и Ко.

Гальперин, И. Р. (2006). Текст как объект лингвистического исследования. КомКнига.

Гончарова, Л. М. (2008). Позитивно настраивающие тактики. Язык средств массовой информации как объект междисииплинарного исследования: материаль II междун. науч. конф. Моск., филолог. факул. МГУ им. М. В. Ломоносова, 339-343.

Карасик, В. И. (2002). Языковой круг: личность, концепты, дискурс. Перемена.

Кафтанджиев, Х. (1995). Тексты печатной рекламы. Смысл.

Красных, В. В. (1997). Когнитивная база и прецедентные феномены в системе других единиц и в коммуникации. Вестник Моск. гос. ун-та. Серия «Филология», 3, 62-75.

Куликова, В. Е. (2008). Языковая специфика рекламного дискурса. Вестник Нижегородского университета им. Н.И. Лобачевского, 4, 197-205.

Кухаренко, В. А. (2000). Практикум з стилістики англійської мови. Вінниця: Нова книга.

Медведева, Е. В. (2003). Рекламная коммуникация. УРСС.

Acura. (2018). Acura. Retrieved from https://www.acura.com/

Audi. (2020). Audi Exclusive. Retrieved from https://www.audi.com/en/experience-audi/models-and-technology/audiexclusive.html

Chevrolet. (2017). Chevrolet. Retrieved from https://www.chevrolet.com/

Dodge. (2020). Dodge Durango. Retrieved from https://www.savagedodge.net/shop-2019-dodge-durango-readingpa.html

Edwards, Ch. M. (1981). Retail Advertising and Sales Promotion. New York.

Leech, G. (1966). English in Advertising: A linguistic Study of Advertising in Great Britain. Longman.

Hyundai. (2015). Hyundai. Retrieved from https://www.hyundaimotor.com.mm/download.html

Jaguar. (2019). Jaguar. Retrieved from https://www.jaguarusa.com/index.html

Magna. (2019). Magna. Retrieved from https://www.magna.com

Mazda. (2020). Mazda. Retrieved from https://www.mazda.com/

Maserati. (2020). GranTurismo. Retrieved from https://www.maserati.com/international/en/models/granturismo

Mercedes-Benz. (2019). Mercedes. Retrieved from https://www.mercedes-benz.com/en/

Schiffrin, D., Maznevski, M., \& Tannen, D. (2003). Handbook of Discourse Analysis. Wiley.

Skoda. (2018). Skoda. Retrieved from https://www.skoda.co.uk/

$\begin{array}{lllllll}\text { Toyota. (2018). } & \text { Toyota } & - & \text { Let's } & \text { Go } & \text { Places. } & \text { Retrieved }\end{array}$ https://www.toyota.com/usa/careers/articles/careers_plano.html

Vauxhall. (2016). Vauxhall. Retrieved from https://www.vauxhall.co.uk/

Volvo. (2020). Volvo Trucks. Retrieved from https:/www.volvotrucks.com/en-en/trucks/trucks/volvo-fh16-classic.html

\section{REFERENCES (transliterated and translated)}

Acura. (2018). Acura. Retrieved from https://www.acura.com/ [in English]

Audi. (2020). Audi Exclusive. Retrieved from https://www.audi.com/en/experience-audi/models-and-technology/audiexclusive.html [in English]

Alekseieva, I. S. (2004). Vvedenie v perevodovedenie [Introduction to translation studies]. Akademija. [in Russian] Arutiunova, N. D. (1999). Jazyk i mir cheloveka [Language and man's world]. Jazyki russkoj kul'tury. [in Russian]

Batsevych, F. S. (2006). Vstup do linhvistychnoi henolohii [Introduction to linguistic genealogy]. Vydavnychyi tsentr "Akademiia." [in Ukrainian]

Berdyshev, S. N. (2008). Reklamnyj tekst. Metodika sostavlenija i oformlenija [Advertising text. Methodology of completion and formation]. Dashkov i Ko. [in Russian]

Chevrolet. (2017). Chevrolet. Retrieved from https://www.chevrolet.com/ [in English]

Dodge. (2020). Dodge Durango. Retrieved from https://www.savagedodge.net/shop-2019-dodge-durango-readingpa.html [in English] 
Edwards, Ch. M. (1981). Retail Advertising and Sales Promotion. New York. [in English]

Gal'perin, I. R. (2006). Tekst kak obekt lingvisticheskogo issledovanija [Text as an object of linguo-stylistic research]. KomKniga. [in Russian]

Goncharova, L. M. (2008). Pozitivno nastraivajushhie taktiki [Positive tactics]. Jazyk sredstv massovol̆ informacii kak obekt mezhdisciplinarnogo issledovanija: materialy II mezhdun. nauch. konf. Moskva: Mosk., filolog. fakul. MGU im. M. V. Lomonosova, 339-343. [in Russian]

Hyundai. (2015). Hyundai. Retrieved from https://www.hyundaimotor.com.mm/download.html [in English]

Jaguar. (2019). Jaguar. Retrieved from https://www.jaguarusa.com/index.html

Karasik, V. I. (2002). Jazykovoj krug: lichnost', koncepty, diskurs [Language circle: personality, concepts and discourse]. Peremena. [in Russian]

Kaftandzhiev, H. (1995). Teksty pechatnoj reklamy [Texts of printed advertisement]. Moskva: Smysl. [in Russian]

Krasnyh, V. V. (1997). Kognitivnaja baza i precedentnye fenomeny v sisteme drugih edinic i v kommunikacii [Cognitive base and precedent phenomena in the system of other units and in communication]. Vestnik Mosk. gos. un-ta. Serija „Filologiia“, 3, 62-75. [in Russian]

Kulikova, V. E. (2008). Jazykovaja specifika reklamnogo diskursa [Specifics of advertising language]. Vestnik Nizhegorodskogo universiteta im. N.I. Lobachevskogo, 4, 197-205. [in Russian]

Kukharenko, V. A. (2000). Praktykum z stylistyky anhliiskoi movy [Practicum on English stylistics]. Vinnytsia: Nova knyha. [in Ukrainian]

Leech, G. (1966). English in Advertising: A linguistic Study of Advertising in Great Britain. Longman. [in English]

Magna. (2019). Magna. Retrieved from https://www.magna.com [in English]

Mazda. (2020). Mazda. Retrieved from https://www.mazda.com/ [in English]

Maserati. (2020). GranTurismo. Retrieved from https://www.maserati.com/international/en/models/granturismo [in English]

Medvedeva, E. V. (2003). Reklamnaja kommunikacija [Advertising communication]. URSS. [in Russian]

Mercedes-Benz. (2019). Mercedes. Retrieved from https://www.mercedes-benz.com/en/ [in English]

Schiffrin, D., Maznevski, M., \& Tannen, D. (2003). Handbook of Discourse Analysis. Wiley. [in English]

Skoda. (2018). Skoda. Retrieved from https:/www.skoda.co.uk/ [in English]

Toyota. (2018). Toyota - $\quad$ Let's Go Places. $\quad$ Retrieved from

https://www.toyota.com/usa/careers/articles/careers_plano.html [in English]

Vauxhall. (2016). Vauxhall. Retrieved from https://www.vauxhall.co.uk/ [in English]

Volvo. (2020). Volvo Trucks. Retrieved from https:/www.volvotrucks.com/en-en/trucks/trucks/volvo-fh16-classic.html [in English]

Yana Tikan, Valeriia Andreieva. Linguo-stylistic peculiarities of English advertising texts in the field of mechanical engineering. The article studies linguo-stylistic peculiarities of English advertising texts in the field of mechanical engineering. Advertising text is one of the relevant topics for linguistic research, as advertising is a dynamic phenomenon. Its development predetermines the systematization of linguo-stylistic peculiarities within English advertising texts. The aim of the article is to analyse the use of expressive linguo-stylistic devices in English-language advertising texts in the field of mechanical engineering considering their structural composition. The subject of research is English-language advertising texts in the field of mechanical engineering. The article theoretically substantiates the terminological apparatus of the research: different approaches of scientists to the interpretation of the concepts "advertising", "advertising text" and "advertising discourse" were considered. The structural features of the advertising text and their functions are also analysed. The article provides several classifications of leading scholars, on the basis of which further analysis was conducted. The study was based on the official English-language sites of such leading companies in the industry as BMW, Jaguar, Toyota, Honda, Mazda, Mercedes-Benz, Ford, Lexus, Saturn, Audi, Subaru, Suzuki, Hyundai and others. The article focuses on the examples of expressive linguo-stylistic devices in each of the structural elements of the English advertising text in the field of mechanical engineering, taking into account the frequency of their use. The peculiarities of their functioning in media texts were also analyzed, considering pragmatics and communication strategies aimed at the recipient of the advertising message. In the course of the analysis, manipulative features of linguo-stylistic devices were indicated and outlined with the help of relevant examples.

Keywords: advertising; advertising text; advertising discourse; field of mechanical engineering; linguostylistic peculiarities; manipulative features. 